\title{
Patterns of Shocks and Regional Currency for the Pacific Islands
}

\author{
T. K. Jayaraman \\ The University of the South Pacific
}

\begin{abstract}
The fourteen Pacific island countries, under the auspices of their regional organization known as the Pacific Forum, launched two major initiatives in 2002 to introduce unhindered trade amongst themselves by 2010 and usher in an enlarged free trade area with Australia and New Zealand by 2015. Thus, trade integration efforts are expected to lead to greater economic integration of the region. In the meanwhile, in 2003 Australia mooted the idea of a single currency for the region as a whole. Although the Pacific Forum, which also includes Australia and New Zealand, has not formally discussed the proposal so far, there is considerable debate ongoing on the subject of common currency. This paper examines the patterns of shocks, which have affected the region during the last two decades; seeks to investigate whether these shocks have been of similar nature; and evaluates whether these countries are presently suitable candidates for a currency union so that union-wide policies in the event of a currency union can be successfully pursued.
\end{abstract}

- JEL classifications: F3, F4

- Key words: Pacific Islands, Shocks, Currency Union

\footnotetext{
*Corresponding address: T. K. Jayaraman, School of Economics, Faculty of Business and Economics, The University of the South Pacific, Laucala Campus, Laucala Bay Road, Suva, Fiji Islands. Tel: +679323-2178/2547, Fax: +679-323-2522/1506,_E-mail: jayaraman_tk@usp.ac.fj

(C2006-Center for International Economics, Sejong Institution, All Rights Reserved.
} 


\section{Introducton}

The successful introduction of the euro in Europe, just before the new millennium began, has rekindled interest in economic integration of the South Pacific islands. Although there have been many such efforts for some time now in developing countries in other regions ${ }^{1}$, there has been no similar attempt so far in the South Pacific region. Initiatives in 2002 towards free trade by 2010 amongst the Pacific island countries $(\mathrm{PICs})^{2}$, which are considered as steppingstones, aiming at a larger free trade area later with Australia and New Zealand ${ }^{3}$ are, therefore, just a beginning. Close on the heels of two agreements signed in 2002, came a recommendation in March 2003 from an Australian Senate Committee (2003). The Senate Committee, which studied Australia's relations with the PICs, suggested the adoption of a common currency, preferably the Australian dollar as part of efforts toward ushering in a Pacific Economic and Political Community.

Following the Senate Committee's recommendation, it was no surprise that Australia floated the idea of adopting a common currency for the region during the annual Pacific Forum Leaders' meeting held in Auckland in August 2003, which was attended by the prime ministers and presidents of the 14 PICs and the prime ministers of Australia and New Zealand. Since the proposal of single currency was not included as an item in the agenda, it was not formally discussed. The response to the Australian proposal was, however, not very warm (Chand 2003). New Zealand and the PICs preferred to remain silent on the proposal made at the meeting. It was felt that Australia had been too quick to propose a common currency, which is the ultimate concept or nirvana of political and economic integration. The

${ }^{1}$ These include: Communauté financière africaine (CFA), consisting of two zones, West African Monetary Union, and Central African Economic and Monetary Union in Africa (Hernandez-Cata et al., 1998; Cobham \& Robson, 1994; Collier, 1991); the rand zone; the Eastern Caribbean Currency Union (ECCU) within the Organization of Eastern Caribbean States (OECS); and the Caribbean Community and Common Market (CARICOM) in the Caribbean region (Samuel, 2001; Hilaire, 2000, 2001; Van Beek, 2000; Hilaire et al., 1994; Blackman, 1998; Demas, 1974), with which PICs share many commonalities (Fairbairn \& Worrell, 1996)

${ }^{2}$ The 14 PICs are: Cook Islands, Fiji, Kiribati, Republic of Marshall Islands, Federated States of Micronesia, Nauru, Niue, Palau, Papua New Guinea (PNG), Samoa, Solomon Islands, Tonga, Tuvalu and Vanuatu.

${ }^{3}$ The two agreements signed in 2002 are known as the Pacific Agreement on Closer Economic Relations (PACER) and the Pacific Island Countries Trade Agreement (PICTA). The PACER was signed by 16 countries including Australia and New Zealand and 14 PICs for starting negotiations by 2011. The PICTA was signed only by 14 PICs for setting up a free trade area amongst themselves by 2010 . 
critics believe that the most critical element required for an economic union, namely regional solidarity, which evolved over a 50-year period in Europe before culminating in an economic union, is absent in the South Pacific.

A former Governor of New Zealand's central bank (Brash 2001), not long ago, had gone on record that the time for adopting the Australian dollar as a common currency for both the countries was not ripe on the ground that conditions required for formation of an optimum currency area (OCA), originally expounded by Mundell (1961) have not been fulfilled. The OCA conditions were subsequently elaborated and have been updated from time to time by empirical studies including Bayoumi, Eichengreen and Mauro (2000), Eichengreen and Bayoumi (1999) and International Monetary Fund (1997).

Aside from assessing the degree of political commitment, one has also to assess whether there is an economic case in the South Pacific for a single currency. One of the OCA conditions relates to the prime pre-requirement of large intra-trade volume among the prospective members of a currency union so that there could be immediate and substantial gains flowing out of common currency, mainly in terms of savings in transaction costs as well as arising out of absence of volatility in exchange rate movements. Further, a common currency entails a single set of economic, monetary, financial and fiscal policies to influence the balance of payments of the region. Such a single set of policies can be justified only when all the prospective member countries face a similar pattern of shocks. Countries experiencing common external shocks would be better suited to a currency union because it permits the use of union-wide policies to correct any imbalances, including the adjustment of the common currency (Mundell 1961).

The pattern of shocks would determine nature of the cost of surrendering monetary sovereignty, as the member countries cannot follow independent monetary and exchange rate policies for adjustment. If they face similar shocks, the costs of losing tools of adjustment would be lower than otherwise (Bayoumi, Eichengreen, and Mauro 2000, Maskay 2003). Masson and Taylor (1993) observed that while there were many OCA criteria, including openness, intra-trade volume, and labor mobility, the shock-absorption criterion combines the net influence of several traditional criteria pointing to the choice of the optimal exchange rate. This particular property eliminates the problems arising out of conflicting policy prescriptions, which emanate from the application of individual OCA criteria (Maskay 2003). Accordingly, this paper uses the criterion of shock absorption for determining whether PICs could be candidates for a currency union with Australia 
adopting the Aussie dollar or for a currency union amongst themselves, keeping Australia out, with a common currency of their own.

The paper is organized into three sections. The first section provides a brief background of the Pacific island economies discussing their current trade patterns and their efforts towards regional integration; the second section deals with the methodology employed in the study for measuring the pattern of underlying disturbances the PICs have been facing and reports the results of the empirical analysis. The third and final section presents some conclusions.

\section{Economic Integration Efforts in the Pacific Island Countries}

The PICs exhibit considerable diversity of culture and language as well as great variation in physical endowments. Land area varies from country to country: 24 sq. $\mathrm{km}$ in case of Nauru to 462,840 sq. km in the case of Papua New Guinea (PNG). So too is population (Table 1), the most populous nation being PNG (5.1

Table 1. Key indicators of Pacific Island Countries

\begin{tabular}{|c|c|c|c|c|c|c|c|c|c|}
\hline Country & $\begin{array}{l}\text { Land } \\
\text { Area } \\
\text { sq.km }\end{array}$ & $\begin{array}{l}\text { Populatios } \\
\text { ('000) } \\
(2002)\end{array}$ & $\begin{array}{c}\text { Exclusive } \\
\text { Economic } \\
\text { Zone } \\
\text { ('000 } \\
\text { sq.km) }\end{array}$ & $\begin{array}{c}\text { Total } \\
\text { GDP } \\
\text { (US\$ } \\
\text { mill) } \\
(2001)\end{array}$ & $\begin{array}{c}\text { Per capita } \\
\text { GDP } \\
\text { (US\$) } \\
(2001)\end{array}$ & $\begin{array}{l}\text { a Aid } \\
\text { per capita } \\
\text { (US\$) } \\
(2000)\end{array}$ & $\begin{array}{l}\text { Aid as } \\
\text { per cent } \\
\text { of GDP } \\
(2000)\end{array}$ & $\begin{array}{c}\text { Human } \\
\text { Develpt } \\
\text { Index } \\
\text { (1999) }\end{array}$ & $\begin{array}{c}\text { Global } \\
\text { HDI } \\
\text { Rank } \\
(1999)\end{array}$ \\
\hline Cook Islands & 240 & 19 & 1,830 & 51 & 2,651 & 420 & 15.9 & 0.822 & 62 \\
\hline Fiji & 18,272 & 799 & 1,260 & 1,605 & 2,008 & 46 & 2.3 & 0.667 & 101 \\
\hline Kiribati & 690 & 85 & 3,550 & 45 & 530 & 203 & 38.4 & 0.515 & 129 \\
\hline $\begin{array}{l}\text { Marshall } \\
\text { Islands }\end{array}$ & 170 & 51 & 2,131 & 102 & 2,008 & 1,438 & 49.3 & 0.563 & 121 \\
\hline Micronesia & 701 & 114 & 2,978 & 213 & 1,864 & 1,010 & 54.1 & 0.569 & 120 \\
\hline Nauru & 24 & 12 & 320 & 81 & 7,017 & 183 & 2.6 & 0.663 & 103 \\
\hline Niue & 259 & 2 & 390 & 7 & 4,773 & 2,720 & 58.6 & 0.774 & 70 \\
\hline Palau & 487 & 19 & 601 & 129 & 6,989 & 2,168 & 31.1 & 0.861 & 46 \\
\hline $\begin{array}{l}\text { Papua } \\
\text { New Guinea }\end{array}$ & $3,120,000$ & 5,099 & 468 & 4,232 & 830 & 82 & 8.5 & 0.314 & 164 \\
\hline Samoa & 2,857 & 175 & 120 & 177 & 1,004 & 208 & 20.6 & 0.590 & 117 \\
\hline $\begin{array}{l}\text { Solomon } \\
\text { Islands }\end{array}$ & 28,446 & 418 & 1,630 & 300 & 720 & 102 & 14.4 & 0.371 & 147 \\
\hline Tonga & 699 & 98 & 700 & 173 & 1,763 & 252 & 14.3 & 0.647 & 107 \\
\hline Tuvalu & 26 & 11 & 757 & 4 & 345 & 471 & 130.0 & 0.583 & 118 \\
\hline Vanuatu & 12,189 & 183 & 680 & 241 & 1,319 & 223 & 16.8 & 0.425 & 140 \\
\hline
\end{tabular}

Source: US General Accounting Office (2001)

Australian Agency for International Development (2001)

Asian Development Bank (2003) 
million) and the least being Niue (2,000). While Kiribati and Tuvalu are atoll countries with poor soils and hence with limited agricultural possibilities, PNG, the Solomon Islands, Fiji, Samoa and Tonga have relatively large tracts of fertile land, with substantial agricultural potential.

Despite these variations, the economic challenges faced by all PICs are similar: small domestic markets and remoteness from major markets (Urwin 2004). They have to depend upon imports for almost all basic commodities; and rely upon a very few exports such as fish, copra, timber and tourism (Table 2) and on remittances from migrant seafaring men, to finance their imports. Almost all PICs

Table 2. Main Merchandise Exports and Tourism Earnings of FICs (Averages of 1996-1999)

\begin{tabular}{|c|c|c|c|}
\hline \multirow{2}{*}{ Country } & \multicolumn{2}{|c|}{ Main Merchandise Exports } & \multirow{2}{*}{$\frac{\text { Tourism Earnings }}{\text { (\% of Exports of Goods \& Services) }}$} \\
\hline & (per cent of Total Mer & lise Exports) & \\
\hline \multirow[t]{2}{*}{ Fiji } & Sugar & 27.1 & 25.1 \\
\hline & Garments & 23.1 & \\
\hline \multirow[t]{2}{*}{ Kiribati } & Copra & 52.1 & 14.2 \\
\hline & Seaweed & 7.8 & \\
\hline \multirow{2}{*}{$\begin{array}{l}\text { Marshall } \\
\text { Islands }\end{array}$} & Fish & 66.1 & 8.3 \\
\hline & Coconut oil & 12.1 & \\
\hline \multirow[t]{2}{*}{ Micronesia } & Fish & 88.1 & 7.6 \\
\hline & Garments & 6.2 & \\
\hline \multirow[t]{3}{*}{ PNG } & Gold & 30.1 & - \\
\hline & Copper & 19.4 & \\
\hline & Crude Oil & 18 & \\
\hline \multirow[t]{2}{*}{ Samoa } & Coconut oil & 28.1 & 51.3 \\
\hline & Copra & 15.9 & \\
\hline \multirow{2}{*}{$\begin{array}{l}\text { Solomon } \\
\text { Islands }\end{array}$} & Timber & 51.1 & ;- \\
\hline & Palm Oil & 11.1 & - \\
\hline \multirow[t]{2}{*}{ Tonga } & Squash & 44.4 & 29.1 \\
\hline & Fish & 19.6 & \\
\hline \multirow[t]{2}{*}{ Vanuatu } & Copra & 40.2 & 41.7 \\
\hline & Beef & 12.1 & \\
\hline
\end{tabular}

Source: Asian Development Bank (2003) 
depend heavily on foreign aid. The aid inflows have continued from their former colonial masters despite their political independence in the late 1970s. As part of historical legacy, they have inherited large sized public sectors. The private sectors of PICs are weak. Further, being located on the hurricane belt, most of the PICs are prone to annual natural disasters and other causes of environmental degradation.

The PICs are open economies-in several cases this is not because they have low trade barriers but because they are small and therefore have large import flows. Their trade volumes in commodities (exports and imports) expressed as percentages of gross domestic product are fairly high. In 2000, they ranged from 120 per cent in Kiribati to 68 per cent in Republic of Marshall Islands (RMI). Exports of PICs are limited in range. While PNG's major exports are gold, petroleum, copper, timber and coffee, Fiji's main exports are sugar, garments and gold. For smaller island countries, which have negligible manufacturing capacity, reliance on primary exports is much greater. For Samoa, exports are fish, copra and related products; for Tonga squash, fish and root crops; and for Vanuatu, beef, copra and cocoa (Table 2). Thus, PICs are generally more competitive than complementary to each other.

Intra-PIC trade has been small (Table 3). The major intra-regional trading partners are Fiji and PNG, understandably because of their significant manufacturing base. Fiji has been exporting to other PICs processed consumer goods in fairly large volumes, such as wheat flour, cooking oil and biscuits. On the other hand, Fiji's imports from other PICs are confined to a very small volume of agricultural commodities. PNG exports coffee and other manufactured goods. Thus, only these two PICs, PNG and Fiji are substantially diversified. As a result, the PICs lack product diversity.

In terms of percentages of GDP intra-regional trade volume in 2000 varied from 59 per cent in Tuvalu which imports substantial consumer goods from Fiji, to 0.01 percent in the Federated States of Micronesia (FSM), which imports most of its consumer goods from the United States of America. In terms of percentages of total trade, intra regional imports range from 56 per cent in the case of Tuvalu to 0.02 per cent in the case of FSM. Only under exceptional circumstances, such as cyclones or poor agricultural seasons, do PICs import staples such as root crops from other PICs. For instance, in the early 1990s, when coconut palms in Tonga were uprooted by cyclones, coconuts were imported from Samoa. Likewise, in the mid 1990s when the taro leaf blight severely damaged root crops in Samoa, resulting in poor yields for three years, large volumes of taro were imported from 
Table 3. Intra-regional Exports and Imports of PICs

\begin{tabular}{|c|c|c|c|c|c|c|c|c|c|c|}
\hline \multirow{2}{*}{\multicolumn{2}{|c|}{ Countries }} & $\begin{array}{c}\text { Intra- } \\
\text { Reg }\end{array}$ & & $\begin{array}{c}\text { Intra- } \\
\text { Reg } \\
\text { Trade }\end{array}$ & $\begin{array}{c}\text { Intra- } \\
\text { Reg }\end{array}$ & $\begin{array}{l}\text { Exports } \\
\text { to }\end{array}$ & $\begin{array}{l}\text { Imports } \\
\text { from } \\
\text { Australia }\end{array}$ & Exports to & $\begin{array}{l}\text { Imports } \\
\text { from } \\
\mathrm{NZ}\end{array}$ & $\begin{array}{l}\text { Total } \\
\text { Trade }\end{array}$ \\
\hline & & $\begin{array}{l}\text { Exports } \\
\text { (percent } \\
\text { of Total } \\
\text { Exports) }\end{array}$ & $\begin{array}{l}\text { Imports } \\
\text { (per cent } \\
\text { of Total } \\
\text { Imports) }\end{array}$ & $\begin{array}{l}\text { (percent } \\
\text { of Total ( } \\
\text { Trade) }\end{array}$ & $\begin{array}{l}\text { Trade } \\
\text { (percent } \\
\text { of GDP) }\end{array}$ & $\begin{array}{l}\text { Australia } \\
\text { (per cent } \\
\text { t of Total } \\
\text { Exports) }\end{array}$ & $\begin{array}{l}\text { (per cent } \\
\text { of Total } \\
\text { Imports) }\end{array}$ & $\begin{array}{c}\text { NZ } \\
\text { (per cent } \\
\text { of Total } \\
\text { Exports) }\end{array}$ & $\begin{array}{l}\text { (per cent } \\
\text { of Total } \\
\text { Imports) }\end{array}$ & $\begin{array}{c}\text { (per } \\
\text { cent of } \\
\text { GDP) }\end{array}$ \\
\hline \multicolumn{2}{|c|}{ Cook Is Average of 1994-1997 } & - & 10.26 & 9.52 & 4.9 & 21.07 & 7.19 & 25.51 & 70.94 & 51.43 \\
\hline & 1998 & - & 11.76 & 10.83 & 5.6 & 28.3 & 9.75 & 10.4 & 68.2 & 52.45 \\
\hline & 1999 & - & 10.44 & 9.82 & 5.2 & 9.32 & 8.2 & 25.2 & 68.94 & 54.85 \\
\hline & 2000 & - & 18.49 & 15.68 & 12.03 & 33.91 & 5.97 & 25.13 & 60.58 & 76.73 \\
\hline & 2001 & - & 11.12 & 9.74 & 6.77 & 29.12 & 6.1 & 8.2 & 74.83 & 74.4 \\
\hline & 2002 & - & 6.2 & 5.6 & 3.41 & 22.08 & 6.85 & 13.9 & 79.07 & 61.5 \\
\hline \multirow[t]{6}{*}{ Fiji } & Average of 1994-1997 & 0.31 & 0.07 & 0.38 & 0.505 & 26.67 & 39.86 & 6.99 & 15.50 & 76.87 \\
\hline & 1998 & 4.73 & 0.12 & 2.13 & 0.73 & 33.79 & 44.84 & 4.31 & 15.11 & 86.84 \\
\hline & 1999 & 6.84 & 0.1 & 2.81 & 0.64 & 33.02 & 41.09 & 4.47 & 13.10 & 90.62 \\
\hline & 2000 & 7.11 & 0.14 & 3.35 & 0.94 & 25.67 & 48.71 & 3.53 & 13.04 & 89.62 \\
\hline & 2001 & 8.33 & - & 3.7 & 0.07 & 19.74 & 44.26 & 3.46 & 14.88 & 82.5 \\
\hline & 2002 & 7.21 & - & 3.02 & 0.06 & 19.43 & 37.31 & 3.76 & 17.15 & 89.26 \\
\hline \multicolumn{2}{|c|}{ Kiribati Average of 1994-1997 } & - & 7.8 & 5.15 & 11.67 & 3.02 & 18.11 & & 3.94 & 88.78 \\
\hline & 1998 & - & 10.01 & 8.7 & 17.06 & 4.05 & 21.82 & - & 1.69 & 102.74 \\
\hline & 1999 & - & 14 & 11.37 & 16.31 & 2.59 & 33.08 & - & 3.02 & 98.02 \\
\hline & 2000 & - & 14.21 & 10.7 & 22.26 & 0.24 & 34.12 & - & 4.75 & 80.98 \\
\hline & 2001 & - & 20.8 & 11.87 & 21.53 & 0.39 & 37.16 & - & 2.91 & 91.87 \\
\hline & 2002 & - & 12.67 & 9.14 & 20.69 & 0.38 & 26.6 & - & 3.58 & 124.74 \\
\hline \multirow[t]{6}{*}{ RMI } & Average of 1994-1997 & - & 0.97 & 0.71 & 0.46 & - & 1.31 & - & 1.01 & 83.41 \\
\hline & 1998 & - & 0.78 & 0.7 & 0.35 & - & 2.01 & - & 0.71 & 67.93 \\
\hline & 1999 & - & 1.16 & 1.02 & 0.5 & - & 1.42 & - & 0.85 & 68.94 \\
\hline & 2000 & - & 1.25 & 1.05 & 0.54 & - & 1.46 & - & 0.89 & 68.33 \\
\hline & 2001 & & NA & NA & NA & NA & NA & NA & NA & 61.3 \\
\hline & 2002 & & NA & NA & NA & NA & NA & NA & NA & 67.62 \\
\hline \multirow[t]{6}{*}{ FSM } & Average of 1994-1997 & 0.01 & - & 0.01 & 0.01 & NA & 2.62 & - & - & 65.61 \\
\hline & 1998 & 0.19 & - & 0.02 & 0.01 & NA & 4.02 & - & - & 64.71 \\
\hline & 1999 & 0.2 & - & 0.02 & 0.01 & NA & 19.79 & - & - & 64.39 \\
\hline & 2000 & NA & NA & NA & NA & NA & NA & NA & - & 73.07 \\
\hline & 2001 & NA & NA & NA & NA & NA & NA & NA & NA & 53.05 \\
\hline & 2002 & NA & NA & NA & NA & NA & NA & NA & NA & 52.01 \\
\hline \multirow[t]{6}{*}{$\overline{\mathrm{PNG}}$} & Average of 1994-1997 & 0.03 & 0.03 & 0.06 & 0.11 & 27.68 & 51.43 & 1.39 & 4.01 & 88.89 \\
\hline & 1998 & 0.21 & 0.24 & 0.45 & 0.21 & 18.72 & 52.41 & 0.69 & 4.12 & 94.70 \\
\hline & 1999 & 0.18 & 0.30 & 0.44 & 0.23 & 26.29 & 53.01 & 0.16 & 4.1 & 114.12 \\
\hline & 2000 & 0.21 & 0.36 & 0.57 & 0.29 & 29.98 & 49.54 & 0.73 & 3.8 & 116.45 \\
\hline & 2001 & 0.1 & 0.21 & 0.25 & 0.2 & 24.62 & 51.29 & 1.35 & 4.02 & 94.42 \\
\hline & 2002 & 0.10 & 0.13 & 0.31 & 0.18 & 23.74 & 49.26 & 1.32 & 4.4 & 95.81 \\
\hline
\end{tabular}


Table 3. continued

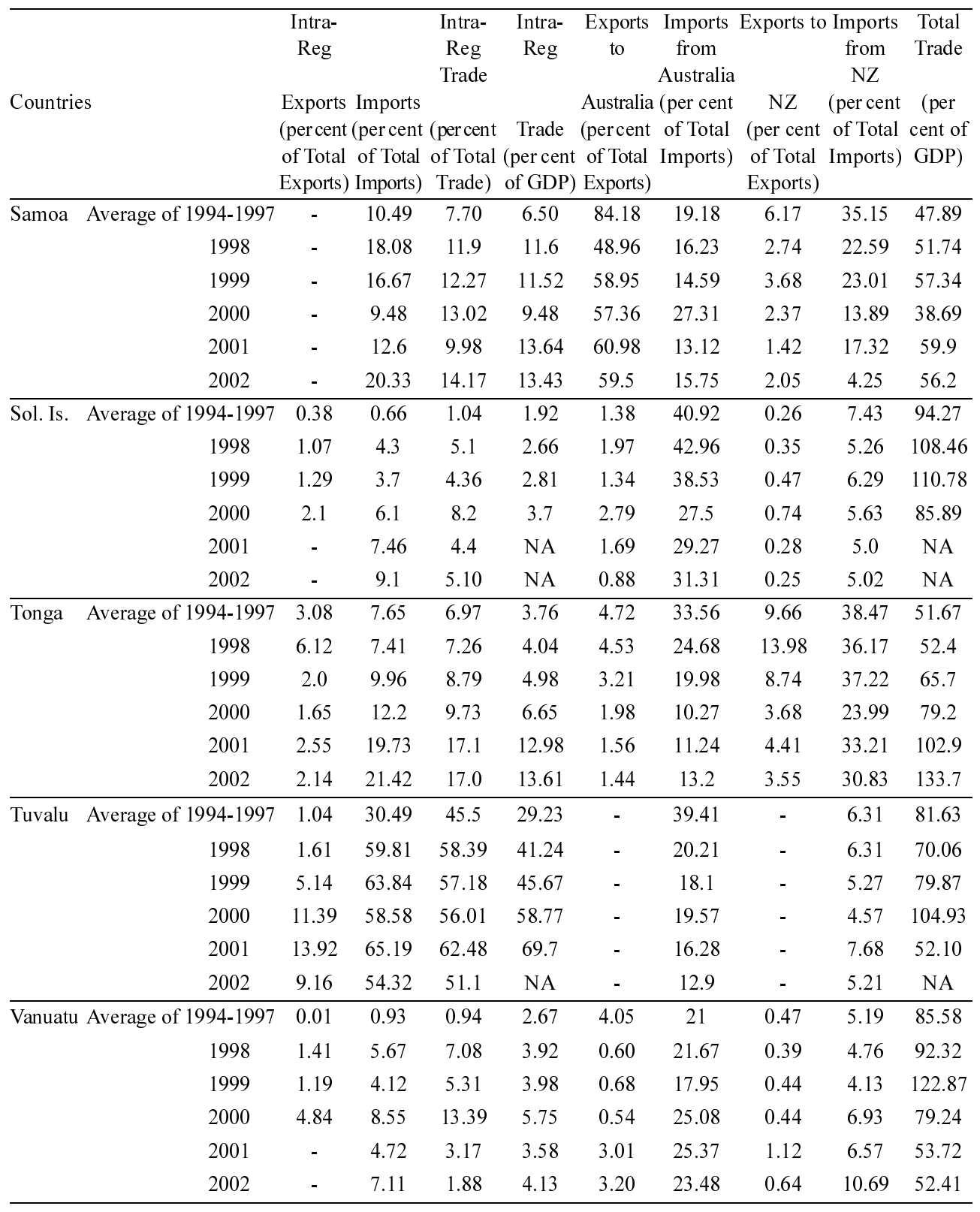

NA: Not available, "-" : negligible Source: Asian Development Bank (2003)

Tonga and other PICs to meet domestic requirements. Thus, any commodity trade between PICs in similar crops has been exceptional.

Since 1993, the preferential trading arrangements under the Melanesian Spearhead Group (MSG) Agreement covering Fiji, Papua New Guinea, Solomon Islands and 
Vanuatu have encouraged intra-regional trade in specified commodities such as coffee, kava and beef. Since 1995, because of a large increase in imports from the other two MSG countries relative to their exports, both Solomon Islands and Vanuatu have accumulated sizeable trade deficits with Fiji and PNG. Consequently, the former two countries in 2002 sought temporary withdrawal from MSG Trade arrangements.

The exchange rate arrangements of PICs vary. They span the continuum from the exclusive use of a foreign currency as legal tender through to an independent and free-floating domestic currency (Table 4). Eight PICs, which do not have an independent domestic currency of their own have adopted the national currencies of Australia, New Zealand or the United States: Kiribati, Nauru and Tuvalu (the Australian dollar); the Cook Islands and Niue (the New Zealand dollar); and FSM, RMI, and Palau (the United States dollar). Five PICs (Fiji, Samoa, Solomon Islands, Tonga and Vanuatu) have their own currencies, pegged to baskets of currencies whose composition and weights are generally kept confidential. PNG, on the other hand, has a freely floating exchange rate regime. Rosales (2001) notes that inflation has been higher in PNG and in those countries, which have been dollarised. In fact, PICs with independent currencies seemed to have done better on the inflation front. Thus, there is nothing remarkable to commend about any specific exchange rate regime in particular.

However, as noted earlier, adopting a common currency will bring about gains to PICs through elimination of currency conversion costs thereby reducing currency transaction costs on products and services as well as costs associated with exchange rate fluctuations. The theory of OCA indicates that gains would be greater, the greater the volume of intra-trade. Since PICs trade a great deal with Australia, gains from adopting the Australian dollar would be substantial. Studies (de Brouwer 2000, Jayaraman 2003) showed that a currency union between PICs without Australia would not result in as much gains as would result from a larger sized union with Australia. However, there are uncertainties regarding the sharing of seignorage revenue with Australia. Further, there are no indications as to whether the Reserve Bank of Australia would be prepared to act as a lender of last resort to commercial banks in crises in PICs (Jayaraman 2004).

PICs in the process of forming a currency union either amongst themselves or with Australia have to surrender their monetary sovereignty as they have to abide by a common set of monetary policies. This requires the presence of a high degree of similarity in the shocks they have been experiencing (Mundell 1961). Countries 
Table 4. Growth rates, Fiscal and External Current Account Balances and Inflation

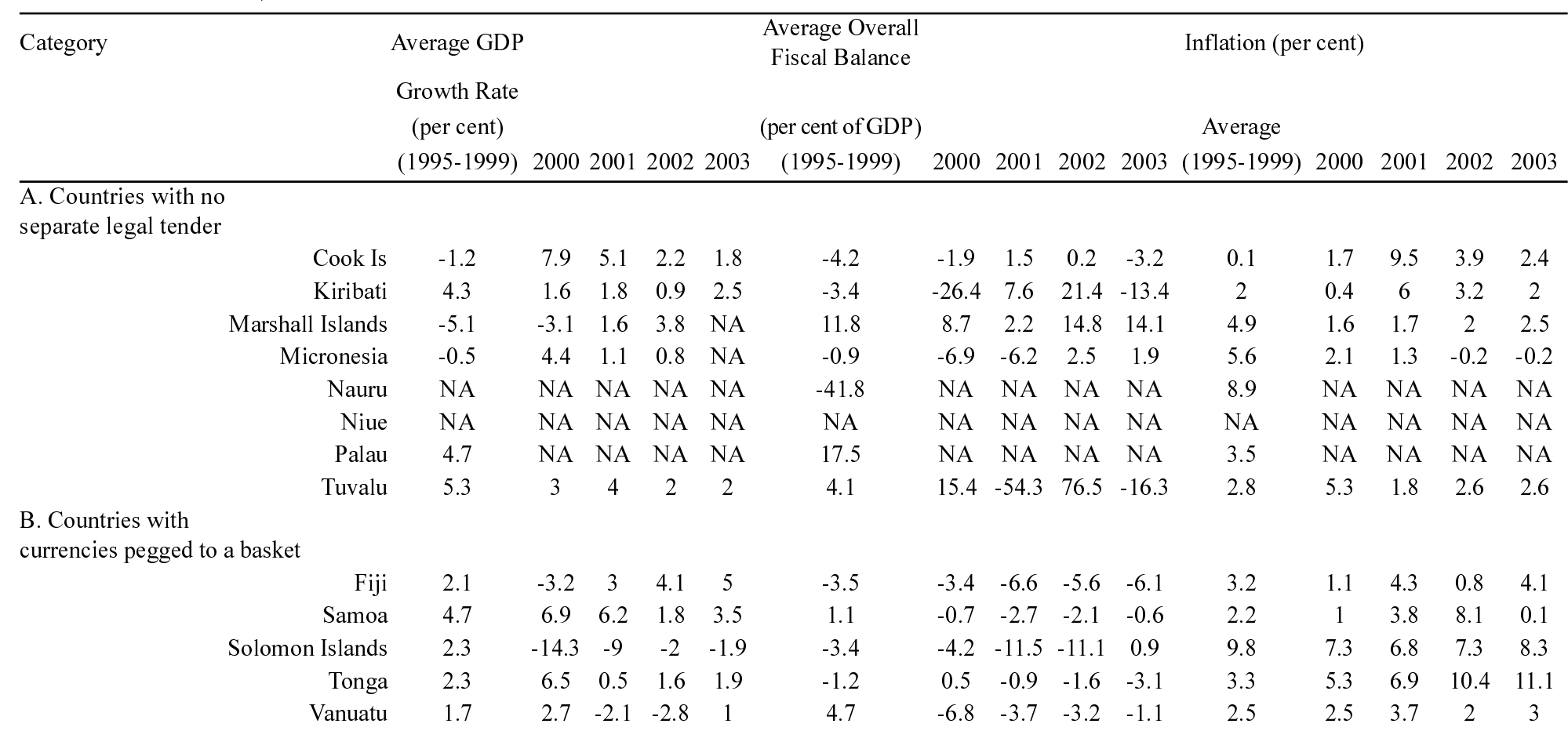

C. Countries with

flexible exchange rate

Papua New Guinea $\quad 0.2 \quad-1.2 \quad-2.3 \quad-0.8 \quad 2$

$-2.1$

$-2 \quad-3.6 \quad-4.1 \quad-1.7$

Source: Rosales (2001), Asian Development Bank, (2003)

United Nations, ESCAP (2004) 
experiencing common external shocks would be better suited to a currency union because it permits the use of union-wide policies to correct any imbalances, including the adjustment of the common currency. Since the currency union would have a single monetary policy, the more asymmetric the external shocks, the greater would be the risk to the stability of the union. Countries are less likely to face large asymmetric terms of trade shocks if they have similar structures (Masson and Pattillo 2001a, 2001b).

Most of the adverse effects of asymmetric shocks, including increases in unemployment and declines in income, would be reduced if there were downward flexibility in prices and wages (Soltwedel, Dohse and Krieger-Boden 2000). In the absence of such downward flexibility, the presence of considerable mobility of labor between member countries would be a great help. Additionally, if the monetary union builds in some provision for a mechanism of fiscal transfer to redistribute income or compensate for differences in unemployment between member countries, the asymmetry of shocks will be less of a problem (Masson and Pattillo 2001a, 2001b; de Brouwer 2000; McKinnon 1963; Kenen 1969).

While the possibilities of downward price and wage flexibility, migration from PICs to Australia and fiscal transfers are all uncertain at this stage, it is at least worthwhile to check whether PICs and the two advanced countries of the region namely Australia and New Zealand have been experiencing symmetrical shocks so as to emerge as candidate countries for a forming currency union. The next section deals with the question in detail.

\section{Empirical Analysis and Results}

Empirical analysis in regard to PICs in particular is highly constrained by data inadequacies. Most of the 14 PICs became independent in the late 1970s and their national statistical offices were set up in the early $1980 \mathrm{~s}^{4}$. As a result, national income data on a consistent time series basis for 11 PICs are available only from 1985 onwards and that too only in terms of annual observations. For other three countries, the data series are incomplete. Therefore, the quantitative treatment is confined to a 19-year period (1985-2003) with observations being limited to annual

\footnotetext{
${ }^{4}$ Much of their national accounts database was built and is being upgraded on a periodical basis through short-time technical assistance provided by Asian Development Bank. In the absence of such technical assistance, the estimates prepared by IMF Art IV Staff Consultation Missions during their biennial visits provide much needed assistance to maintain the database.
} 
ones rather than quarterly.

The analysis is done in two parts: first a simple correlation analysis and secondly, an investigation of shocks during the 19-year period, with a view to assess varying degrees of symmetry.

As any correlation of economic activities across the 14 PICs and the two regional metropolitan powers would be reflected in the correlations of economic growth among the countries, a simple study of correlation coefficients of their GDP growth rates is undertaken. Table 5 presents the correlation matrix of annual growth rates in GDP of 13 countries for the 19-year period, showing both positive and negative correlation between the individual countries. The choice of statistical significance at 5 percent level requires a 45 per cent coefficient of correlation, given the number of observations being $19^{5}$. Out of 78 correlation coefficients, only 10 are found to be significant, which are shown as shaded. Only half of them

Table 5. Correlations of Output Growth Rates of Aus, NZ and Pacific Island Countries: 1985-2003

\begin{tabular}{cccccccccccccc}
\hline & AUS & CI & FJ & FSM & KIR & NZ & PNG & RMI & SAM & SOL & TON & TUV & VAN \\
\hline AUS & 1.000 & & & & & & & & & & & & \\
CI & -0.451 & 1.000 & & & & & & & & & & & \\
FJ & 0.004 & -0.024 & 1.000 & & & & & & & & & & \\
FSM & -0.476 & 0.529 & -0.362 & 1.000 & & & & & & & & & \\
KIR & -0.023 & -0.280 & 0.013 & 0.041 & 1.000 & & & & & & & & \\
NZ & 0.346 & -0.371 & 0.075 & -0.170 & -0.072 & 1.000 & & & & & & & \\
PNG & -0.172 & 0.164 & 0.244 & 0.323 & -0.076 & 0.221 & 1.000 & & & & & & \\
RMI & -0.151 & 0.052 & -0.255 & 0.252 & 0.031 & 0.211 & 0.041 & 1.000 & & & & & \\
SAM & 0.684 & -0.249 & 0.053 & -0.319 & -0.152 & 0.387 & -0.278 & -0.158 & 1.000 & & & & \\
SOL & 0.236 & -0.488 & 0.294 & -0.116 & 0.082 & -0.087 & 0.219 & -0.030 & -0.031 & 1.000 & & & \\
TON & -0.489 & 0.493 & 0.020 & 0.592 & 0.030 & -0.363 & 0.070 & -0.109 & -0.611 & -0.082 & 1.000 & & \\
TUV & 0.041 & 0.155 & 0.252 & -0.156 & 0.270 & -0.268 & -0.029 & -0.285 & -0.181 & -0.022 & 0.134 & 1.000 & \\
VAN & -0.120 & 0.111 & -0.070 & -0.053 & -0.115 & -0.210 & -0.145 & -0.066 & -0.352 & 0.156 & 0.260 & 0.619 & 1.000 \\
SD & 0.015 & 0.042 & 0.037 & 0.041 & 0.058 & 0.025 & 0.062 & 0.080 & 0.079 & 0.056 & 0.028 & 0.0543 & 0.037 \\
\hline
\end{tabular}

?i:!: denotes significance at 5 per cent level

Source: Author's calculations

\footnotetext{
${ }^{5}$ The statistic used for testing the correlation coefficient whether it is significantly different from zero is $\ln [(1+r) /(1-r)] / 2$, where $r$ is the sample correlation coefficient. It has an asymptotically normal distribution with a variance of $(\mathrm{N}-3)$, where $\mathrm{N}$ is the number of observations. Using the level of significance, $\mathrm{a}=0.05$, the rejection region is $\mathrm{Z}=0.5(\mathrm{~N}-3)^{1 / 2}\{\ln [(1+\mathrm{r} /(1-\mathrm{r})]\}>1.96$ (Romano 1970: 156-170). If $\mathrm{N}=19$, $\mathrm{r}$ should be 0.4542 ; if $\mathrm{N}=18$, $\mathrm{r}$ should be 0.4669 ; and if $\mathrm{N}=17$, $\mathrm{r}$ should be 0.4807 .
} 
have positive signs and the remaining five have negative signs. The growth rate of Australia is positively correlated only with that of Samoa, while New Zealand's growth rate is not significantly correlated with any country. Similar are the cases of Fiji, Kiribati, PNG, RMI, and Solomon Islands. Correlation exists only between growth rates of the following pair of countries: Cook Islands and FSM, Cook Islands and Tonga, and FSM and Tonga. The volatility in growth across the countries is reflected in the magnitudes of standard deviation (SD). While Australia's growth displays the least volatility ( 1.5 per cent) represented by its SD, the volatility in RMI's growth is the highest at 8 per cent, followed by Samoa (7.9 per cent) and Kiribati (5.8 per cent). Thus, there is no clear pattern of growth among the countries studied.

Similarity, if any, in the monetary and fiscal policies pursued by each of the 13 countries should give rise to high correlation of inflation rates among them. From Table 6, which reports 78 correlation coefficients, only 24 emerge to be significant at 5 per cent level. Among the significant ones, 18 have positive signs and six have negative signs. Again, as in the case of correlation of growth rates, there is no country coherence in inflation performance.

Limitations to correlation analyses of output growth across countries are well

Table 6. Correlation of Inflation Rates: 1985-2003

\begin{tabular}{lccccccccccccc}
\hline & AUS & CI & FJ & FSM & KIR & NZ & PNG & RMI & SAM & SOL & TON & TUV & VAN \\
\hline AUS & 1.000 & & & & & & & & & & & & \\
CI & 0.710 & 1.000 & & & & & & & & & & \\
FJ & 0.335 & 0.380 & 1.000 & & & & & & & & & & \\
FSM & 0.578 & 0.390 & 0.555 & 1.000 & & & & & & & & & \\
KIR & 0.311 & 0.582 & 0.015 & 0.295 & 1.000 & & & & & & & & \\
NZ & 0.840 & 0.769 & 0.170 & 0.503 & 0.423 & 1.000 & & & & & & & \\
PNG & -0.273 & -0.552 & -0.363 & -0.521 & -0.516 & -0.454 & 1.000 & & & & & & \\
RMI & -0.458 & -0.504 & -0.226 & -0.091 & -0.012 & -0.436 & 0.064 & 1.000 & & & & & \\
SAM & 0.240 & 0.216 & 0.207 & 0.459 & 0.080 & 0.276 & -0.606 & -0.090 & 1.000 & & & & \\
SOL & 0.304 & 0.207 & 0.493 & 0.467 & 0.287 & 0.253 & -0.429 & 0.174 & 0.130 & 1.000 & & & \\
TON & 0.534 & 0.591 & 0.104 & 0.076 & 0.150 & 0.547 & -0.213 & -0.294 & 0.205 & 0.143 & 1.000 & & \\
TUV & 0.414 & 0.319 & 0.169 & 0.163 & -0.032 & 0.249 & 0.068 & -0.144 & -0.372 & 0.331 & 0.426 & 1.000 & \\
VAN & 0.562 & 0.504 & 0.544 & 0.475 & 0.355 & 0.515 & -0.437 & -0.352 & 0.045 & 0.426 & 0.030 & 0.270 & 1.000 \\
\hline
\end{tabular}

:?:! denotes significance at 5 per cent level

Source: Author's calculations 
recognized. Bayoumi and Ostry (1997) observed that such analyses fail to make any distinction between the underlying disturbances themselves. For studying the nature of shocks affecting a given group of countries across different regions in Europe, the Americas and East Asia, Bayoumi and Eichengreen $(1992,1994)$ employed vector autoregression analysis (VAR) to the standard model of aggregate demand and supply. In this procedure, output growth and inflation were regressed upon their own lagged values to decompose output and inflation into underlying aggregate demand and aggregate supply disturbances. Specifically, the model predicts that an expansionary permanent demand shock leads to higher prices and higher output in the short run-only. In the long run, it leads to an increase in prices, leaving the output unchanged. By contrast, a permanent positive supply shock leads to positive output and negative price effects in both the short and long runs. Bayoumi (1992) and Bordo (1993) applied VAR techniques to G-7 countries, while Bayoumi and Eichengreen (1992) employed the same methodology to European countries and various regions in the United States of America. Again Bayoumi and Eichengreen (1994) undertook a similar study for all the highly developed countries around the world. Under the VAR techniques, these authors introduced over-identifying conditions (OICs) that a positive demand shock will cause a price increase while a positive supply shock will cause a price decrease, which confirmed the validity of the decomposition of shocks estimated by VAR technique (Maskay 1998: 544). These studies show that VAR techniques seemed to have worked well when applied to developed countries.

However, Bayoumi and Ostry in their study (1997) of Sub-Saharan African countries as well as Maskay (2003) in his study on South Asian countries conclude that VAR techniques were not well suited for use in the context of developing countries. While VAR technique assumes aggregate demand shocks are assumed to have a temporary impact on output and aggregate supply shocks a permanent impact on output, it did not capture the reality in Sub-Saharan Africa (Bayoumi and Ostry 1997) or in Asia (Maskay 1998, Bajracharya and Maskay 1998), where many of the shocks are temporary supply disturbances such as climatic shocks to agriculture or terms of trade disturbances. Maskay (2003), who had a similar unsuccessful attempt with VAR technique, found the impulse response functions had perverse price responses to supply shocks, which confirmed the difficulties of applying VAR technique to South Asian countries ( Maskay 1998). In addition, there is a major problem, which has been singled out by various researchers in the recent past: the poor quality of data (Bayoumi and Ostry 1997, Summers and Heston 
1991, Maskay 2003).

Bayoumi and Ostry (1997) suggested a way out by focusing only on the behavior of real output. Under this strategy, real output growth rate of each country was regressed upon its own first and second lags (Bayoumi and Ostry 1997: 428). The residuals from the regression were taken as to represent the underlying real output disturbances. As the dataset was small with limited number of observations, the two authors did not make any attempt to decompose and identify the sources of the disturbances, which could reflect various factors including domestic economic policies, external shocks, political instability, civil unrest and droughts (Bayoumi and Ostry 1997: 429). The same procedure was applied to South Asian countries by Maskay (2003). Since decomposition of shocks is not possible in a single equation estimation procedure, where only growth rate was regressed upon its own lags, no OIC was required to be imposed as in the case of the procedure adopting the VAR technique involving both growth rate and inflation.

In the current study on PICs, problems of data quality are well recognized. Morling and Williams in their study (1999), who had difficulties with perverse signs in their study on fluctuations in Fiji's output, understandably cast doubts on reliability of Fiji's national income data. Further, PICs are predominantly agricultural and are subject to frequent weather related supply shocks such as cyclones and volcanic activities, which are temporary nature-a situation, which is very similar to SubSaharan African and South Asian countries. Their exports are also subject to terms of trade shocks as well. In these circumstances, a simpler approach adopted by Bayoumi and Ostry (1997) and Maskay (2003) appears justified.

Accordingly, in our analysis the behavior of real output was focused upon. For consistency sake both the developing PICs and the two advanced countries were subjected to the same treatment. The real output growth rate of each country was regressed upon its both one-and two-period lags. The residuals were taken to represent the underlying disturbances. Since no decomposition of the disturbances is possible due to the constraints introduced by the procedure of focusing on real output, they are taken to represent a host of factors including natural disasters and poor economic policies as well as political instability.

Table 7 presents the correlation matrix of underlying disturbances. As the number of observations is 17 , the choice of significance at 5 per cent level requires a 48 per cent coefficient of correlation. Accordingly, it is observed that out of 78 correlation coefficients only 10 are significant at 5 per cent level. Six of them have positive signs and the other four have negative signs. The result is quite similar to the one 
Table 7. Correlations and Standard Deviation of Underlying Disturbances

\begin{tabular}{lccccccccccccc}
\hline & AUS & CI & FJ & FSM & KIR & NZ & PNG & RMI & SAM & SOL & TON & TUV VAN \\
\hline AUS & 1.000 & & & & & & & & & & & & \\
CI & -0.339 & 1.000 & & & & & & & & & & & \\
FJ & 0.006 & 0.014 & 1.000 & & & & & & & & & & \\
FSM & -0.450 & 0.548 & -0.418 & 1.000 & & & & & & & & & \\
KIR & -0.051 & -0.076 & -0.047 & 0.033 & 1.000 & & & & & & & & \\
NZ & 0.507 & -0.495 & 0.186 & -0.370 & -0.285 & 1.000 & & & & & & & \\
PNG & -0.067 & 0.093 & 0.332 & 0.346 & 0.071 & 0.130 & 1.000 & & & & & & \\
RMI & -0.094 & -0.043 & -0.054 & 0.128 & 0.066 & -0.116 & -0.243 & 1.000 & & & & & \\
SAM & 0.583 & -0.190 & 0.145 & -0.260 & -0.091 & 0.416 & -0.234 & -0.066 & 1.000 & & & & \\
SOL & 0.039 & -0.592 & 0.250 & -0.227 & 0.252 & -0.005 & 0.159 & 0.352 & 0.074 & 1.000 & & & \\
TON & -0.626 & 0.486 & -0.152 & 0.567 & 0.050 & -0.469 & 0.032 & 0.155 & -0.653 & -0.311 & 1.000 & & \\
TUV & -0.151 & 0.197 & 0.208 & -0.202 & 0.259 & -0.353 & 0.056 & 0.076 & -0.448 & -0.064 & 0.167 & 1.000 & \\
VAN & -0.139 & 0.163 & -0.120 & -0.125 & -0.261 & -0.318 & -0.199 & 0.090 & -0.337 & -0.049 & 0.226 & 0.595 & 1.000 \\
SD & 0.013 & 0.040 & 0.037 & 0.041 & 0.056 & 0.024 & 0.060 & 0.054 & 0.076 & 0.047 & 0.027 & 0.053 & 0.039 \\
\hline
\end{tabular}

.?:! denotes significance at 5 per cent level

Source: Author's calculations

obtained in the case of correlations of real growth rates. The conclusion is that the countries studied did not face symmetric patterns of real disturbances during the 19-year period.

The volatility in real shocks faced by the countries is represented by the standard deviation of the residuals of each country (Table 7). The least volatility in real shocks was the one experienced by Australia at 1.3 per cent, followed by New Zealand (2.4 per cent), which are both advanced countries in the region. These two magnitudes are very similar to the results obtained by Bayoumi and Eichengreen (1994) in regard to advanced countries, namely Germany, Japan and the United States. They were in the 2 per cent range. On the other hand, the standard deviations of shocks for all the developing PICs happened to fall in the range of 2.7 per cent to 7.6 per cent. The result was similar to the one arrived at by Bayoumi and Ostry (1997) in the case of African countries.

\section{Conclusions}

This paper examined the viability of a common currency for the Pacific region comprising 14 Pacific island nations and Australia and New Zealand. A high 
degree of similarity in shocks experienced by the countries concerned would be necessary for a successful pursuit of union-wide policies on a consistent basis. Accordingly, the paper undertook a study on the pattern of shocks over a 19-year period (1985-2004) by employing a simpler methodology of regressing each country's growth rate upon its lagged values. Both one year and two-year lags were utilized and the residuals were deemed to reflect the underlying disturbances. The size of underlying disturbances for each country, represented by standard deviation of residuals, varied considerably.

A correlation matrix of these disturbances was calculated. A study of correlation coefficients showed that there was no coherence in the pattern of shocks affecting the 16 countries. In the absence of any similarity in the shocks experienced in the immediate past by the countries studied, it would not be expedient for them to adopt union wide, uniform macroeconomic policies. The policy conclusion stemming from the empirical study is that PICs, either with Australia and New Zealand or exclusively on their own, without involving Australia and New Zealand, are not presently suitable candidates for a currency union.

It should, however, be recognized that most of the literature on OCA conditions, which relate to similarity in economic structures and adjustment policies adopted, fiscal position and inflation, were written in the context of European economic integration. It is now increasingly argued that these OCA conditions do not have much predictive power when applied to actual exchange rate regimes (Masson and Pattillo 2001b, Frankel and Rose 1998). This is based on a strong belief that OCA criteria are to some extent endogenous and that monetary union either in the form of locking one's exchange rate into the major partner's or through adoption of a common currency might help the shocks hitting member countries becoming more symmetric in the long run and would also expand intra-union trade. These observations echo the view expressed by Scitovsky (1958), around the time when the European common market was born, that the common currency arrangements would by themselves tend to make countries similar.

Although the 14 PICs and the region's two advanced countries in the region have in the past faced asymmetric shocks, their economies are closely tradeintegrated. The PIC trade is dominated by Australia and New Zealand. Further, PICs have been the recipients of substantial annual official development assistance flows over several decades; and steadily increasing private foreign domestic investment inflows from Australia and New Zealand. Thus, there is a high degree of dependence as well. Therefore, in the event of a currency union with a common 
currency or adoption of the Australian dollar, the loss to PICs of their monetary and exchange rate policies, as stabilization tools can be compensated by appropriate mechanisms. These mechanisms include flexibility in prices and wages, mobility in labor and other factors of production or fiscal transfers.

The political thinking as reflected in the Senate Committee's recommendation in favour of an eventual Pacific Economic and Political Community (2003) indicates an optimistic atmosphere that current aid flows, which amount to fiscal transfers would be significantly increased; and that there could be relaxation in Australian and New Zealand immigration laws to facilitate seasonal employment for Pacific islanders in agriculture and other selected spheres of economic activities. Such shifts in policy preferences on the lines indicated above would make OCA properties satisfied ex post even if they were not fully satisfied ex ante, as currency union would bring about further closer trade and investment integration in the region.

\section{Acknowledgments}

The author expresses his grateful thanks to the anonymous referees for the constructive criticism and suggestions on an earlier version of the article.

Received 7 September 2004, Accepted 8 April 2005

\section{References}

Asian Development Bank (ADB), 2003. Key Indicators of Asian and Pacific Developing Countries 2001, Asian Development Bank, Manila.

Australian Agency for International Aid for Development (AusAID), (2001), Pacific: Program Profiles: 2000-01, Australian Government Overseas Aid Program, Canberra.

Australian Senate Committee Report, (2003). A Pacific Engaged: Australia's Relations with Papua New Guinea and the Island States of the Southwest Pacific, Commonwealth of Australia, Canberra.

Bajracharya, B.B.and N.M. Maskay (1998). The Aggregate Supply Response for Nepalese Agriculture for the Period 1967/68-1994/95, The Journal of Development and Administrative Studies.

Bayoumi, T. (1992). The Effects of ERM on Participating Economies, International Monetary Fund Staff Papers 39, 330-356.

Bayoumi, T. and B.Eichengreen (1993). Shocking Aspects of European Monetary Unification', 
NBER Working Paper, No.3949.

Bayoumi, T. and B.Eichengreen (1994).One Money or Many? Analyzing the Prospects for Monetary Unification in Various Parts of the World, Princeton's Studies in International Finance, No.76, September.

Bayoumi, T., B.Eichengreen and P.Mauro (2000), The suitability of ASEAN for a regional currency arrangement, IMF Working Paper WP/99/162, IMF, Washington, D.C.

Bayoumi, T. and J.D.Ostry (1997). Macroeconomic Shocks and Trade Flows within SubSaharan Africa: Implications for Optimum Currency Arrangements, Journal of African Economies, 6(4), 412-444.

Blackman, C, (1998), Central Banking in Theory and Practice: A Small State Perspective, Caribbean Center for Monetary Studies, St Augustine, Trinidad.

Bordo, M. 1993. The Gold Standard, Bretton Woods and the Monetary Regimes: A Historical Perspective, Review: Federal Reserve Bank of St.Louis, 75, 123-191

Brash, D. (2000). The Pros and Cons of Currency Union: A Reserve Bank Perspective, An address to the Auckland Rotary Club, 22 May 2000. http://www.rbnz.govt.nz/ speeches/0091114.html

Chand, S (2003). An Assessment of the Proposal for a Pacific Economic and Social Community, Pacific Economic Bulletin, 18 (2), 117-124.

Cobham, D \& P Robson, (1994), Monetary integration in Africa, World Development, 22 (3), 285-99.

Collier, P, (1991), Africa's external economic relations, 1960-90, African Affairs, 90, 339-56.

de Brouwer, G, (2000), Should Pacific Island Countries Adopt the Australian dollar? Pacific Economic Bulletin, 15(2), 161-9.

de Grauwe, P. (1994). The Economics of Monetary Integration, Oxford University Press, New York.

Eichengreen, B. and T. Bayoumi (1999). Is Asia an Optimum Area? Can it Become One?' in Exchange Rate Policies in Emerging Asian Countries, (Ed)S. Collignon, J. PisaniFerry and Y.C. Park (eds.) Routledge, London.

Eichengreen, B and N. Sussman, (2000), 'The International Monetary System in the Very Long Run, Chapter 3 in World Economic Outlook: Supporting Studies, IMF, Washington, DC: 52-85.

Fairbairn, T. I. J., \& D Worrell, (1996), South Pacific and Caribbean Island Economies: A Comparative Study, Foundation for Development Corporation and South Pacific Forum Secretariat, Brisbane and Suva.

Frankel, J.A. and Rose, A.K. (1996). The Endogeneity of the Optimum Currency Area Criteria, National Bureau of Economic Research (NBER) Paper No: 5700, Cambridge, Mass: NBER.

Hernandez-Cata, E and others, (1998), The West African Economic and Monetary Union: Recent Development and Policy Issues, IMF Occasional Paper No. 170, IMF, Washington, D.C.

Hilaire, A, (2000). Caribbean Approaches to Economic Stabilization, IMF Working Paper, 00/73, IMF, Washington, DC. 
Hilaire, A, (2001), Currency Arrangements in Small States, Paper presented at the Conference on Financial Globalization: Issues and Challenges for Small States, Eastern Caribbean Central Bank, St Kitts, 27-28 March.

Hilaire, A, H Codrington, J Robinson and W Samuel, (1994) Options for Monetary Integration in the Caribbean', in Caribbean Monetary Integration, (Eds) T. Farrel and D Worrell Caribbean Information System. Trinidad.

Horvat, J. and R.Grabowski (1997), Prospects of African Integration in Light of the Theory of Optimum Currency Areas, Journal of Economic Integration, 12(1), 1-25.

IMF, (various issues), Directions of Trade, IMF, Washington, D.C.

International Monetary Fund (IMF), (2001) International Experience with Common Currency Arrangements, Paper presented at the Seminar on Common Currency Arrangements and the Exchange Rate Mechanism in ASEAN, August 6-7, Kuala Lumpur.

IMF, (1997). Optimum Currency Areas: New Analytical and Policy Developments, IMF, Washington, DC

Jayaraman, T.K. (2003). Is there a Case for a Single Currency for the South Pacific Island Countries?, Pacific Economic Bulletin, 18(1), 41-53.

Jayaraman, T.K, (2004). A Single Currency for the Pacific Island Countries: A Stepwise Approach, Asia-Pacific Development Journal, 11(1), 91-111.

Kenen, P. B., (1969), The theory of optimum currency areas: an eclectic view', in Monetary Problems of the International Economy, R. Mundell and A. Swoboda (eds.) University of Chicago Press, Chicago: pp.41-60.

Kenen, P. B., (1997), Preferences, Domains, and Sustainability, American Review: Papers and Proceedings, 87(2), 211-13.

Maskay, N.M. (1998). A Comment on Empirical Estimation of Patterns of Shocks Utilizing the VAR Methodology on Developing Countries, Journal of Economic Integration, 13(3), 544-548.

Maskay, N.M.(2000). A Cautionary Note in Using Patterns of Shocks to Determine Optimal Exchange Rate Policy: An Exploration of Nepalese and Indian Exchange Rate Relations of 1964-1994, Applied Economics, 32 (4), 491-498.

Maskay, N.M. (2003). Patterns of Shocks and Regional Monetary Cooperation in South Asia, IMF Working Paper No: WP/03/240, .Washington, D.C.

Masson, P. and C. Pattillo, (2001a), Monetary Union in West Africa: An Agency of Restraint for Fiscal Policies, IMF Working Paper, WP/01/34, IMF, Washington, DC.

Masson, P and C. Pattillo, (2001b), Monetary Union in West Africa (ECOWAS): Is It Desirable and How Could It Be Achieved, Occasional Paper No.204, IMF, Washington, DC.

Masson, P. and M.P.Taylor. (1993). Currency Unions: A Survey of the Issues, in Policy Issues in the Operation of Currency Unions, P. Masson and M.P. Taylor (eds.), Cambridge: Cambridge University Press.

McKinnon, R. I., (1963), Optimum Currency Areas, American Economic Review, 53: $717-24$. 
Morling, S. and G.Williams, (1999). Modelling Output Fluctuations in Fiji, Reserve Bank of Fiji Working Paper 1999/01, Suva: Reserve Bank of Fiji.

Mundell, R., (1961), A Theory of Optimum Currency Areas, American Economic Review, 51: 657-64.

Ng, T.H. (2002). Should the Southeast Asian Countries Form a Currency Union? The Developing Economies, XL (2): 113-34.

Romano, A. (1970). Applied Statistics for Science and Industry, Allyn and Bacon, Inc., Boston.

Rosales, J. R., (2001), Macroeconomic policy and financial sector stability in Pacific island countries, Paper presented at the Conference on Financial Sector Stability and Development, Apia, 2-21 February.

Samuel, W., (2001), Financial integration and currency boards: a case study of the Eastern Caribbean Currency Union, Paper presented at the Conference on Financial Globalisation: Issues and Challenges for Small States, Eastern Caribbean Central Bank, St Kitts and Nevis, 27-28 March.

Soltwedel, R., D.Dohse and C. Krieger-Boden, (2000), EMU challenges to European Labor Markets, Chapter 3 in World Economic Outlook: Supporting Studies, IMF, Washington, DC: 184-210.

Summers, R. and A. Heston, (1993). The Penn World Tables (Mark 5): An expanded Set of International Comparisons, 1950-88, Quarterly Journal of Economics, 106: 327368.

Urwin, G. (2004). Economic Development of Pacific Island Economies and Regional Cooperation, Public Address at the University of the South Pacific, May 18, 2004.

United Nations Economic and Social Commission for Asia and the Pacific (UNESCAP), (2004), Economic and Social Survey 2004, UNESCAP, Bangkok.

United States General Accounting Office (US GAO), (2001). Foreign Assistance: Lessons Learned from Donors' Experiences in the Pacific Region, GAO-01-808, Washington, D.C.

Van Beek, F. and others, (2000), The Eastern Caribbean Currency Union: Institutions, Performance and Policy Issues, IMF Occasional Paper No.195, IMF, Washington, D.C. 